\title{
Environmental migration through the prism of United Nations sustainable development goals
}

\author{
Laura Issova ${ }^{1}$, Almagul Kulbayeva ${ }^{1}$, Mara Gubaidullina ${ }^{1}$, Zhazira Idrysheva ${ }^{1 *}$ \\ and Zhuldyz Kaipzhan ${ }^{1}$ \\ ${ }^{1}$ Al-Farabi Kazakh National University, Kazakhstan, Almaty
}

\begin{abstract}
The article is devoted to the problems of environmental migration in the context of the Sustainable Development Goals proclaimed by the United Nations at the General Assembly session in 2015. Environmental migration has long been the subject of study by various scientists, where in the need for an integrated attitude to the study of this phenomenon is noted. However, to date, there is no systematic approach to studying the problem of environmental migration: scientists consider this process from the point of view of a specific area of their scientific interests. Most often, the points of view of representatives of natural and social sciences are paradigmatically indicated, sometimes they are opposite in their content. The study of environmental migration through the prism of Sustainable Development Goals provides, in our opinion, a comprehensive, interdisciplinary approach. The article attempts to systematically investigate the phenomenon of environmental migration using the consequences of the ecological crisis in the Aral Sea region as an example. Key words: environmental migration, Sustainable Development Goals, United Nations, Aral See, prevent climate change.
\end{abstract}

\section{Introduction}

The first scientific studies of such a social phenomenon as an environmental migration began to be carried out only in the second half of the twentieth century, although the phenomenon itself is characteristic of human history from the very moment of its origin. As noted in many papers on the topic of environmental migration, the term «environmental migrant» was coined by the American ecologist William Vogt [1]. The definition proposed in 1948 is still debatable. Depending on the authorship, the term includes various contexts and is often presented in soft law documents. As defined by the international organization for migration, «environmental migrants are persons or groups of persons who, for serious reasons of sudden or gradual changes in the environment that negatively affect their livelihoods or living conditions, are forced to leave their usual place of residnce or leave it at will for a certain or indefinite time and migrate within or outside their country» [2]; the range of participants in the local conference on refugees, displaced persons, other forms of spontaneous displacement and repatriation in the CIS republics and the corresponding neighboring States characterizes environmental migrants somewhat differently: environmental migrants are persons "who are forced to leave their place of permanent residence and who move within their country or cross its border as a result of a sharp deterioration of the environment or environmental disasters» [3]. At the same time, many UN documents, including Reports of the UN high Commissioner for refugees, UNGA Resolutions, adverse effects of climate change or natural disasters, as well as other environmental factors, are various environmental factors, including the adverse effects of

\footnotetext{
${ }^{1}$ Corresponding author: idrysheva7@ gmail.com
} 
climate change or natural disasters, are one of the main causes of mass population movements in the modern world [4].

The current state of research on the impact of climate on migration is extremely uncertain: they are limited and scattered. Here is no harmony in understanding the real instruments of population migration and the lack of statistical data and empirical research on this topic have an influence on it. The migration context of scientific study is very diverse: some experts point to the direct effect of the environment on migration flows, while others consider the migration movement of the population in the socio-economic and political background. M.Gubaidullina says that «there is a misalignment of water resources behind ecological migration», L.Issova describes «the nature of the western of ecological problems in China's internal migration» [5]. In connection with the aggravation of the environmental crisis more and more representatives of natural Sciences are studying this context of the problem [6,7]. Many researchers consider the problem of environmental migration from the point of view of international law, security issues, human rights, etc. [8]. Another area of research in the framework of environmental migration is the study of regional characteristics of this process [9].

Moreover, the information available in the public domain is very diverse: along with scientific research, there are materials from scientific conferences and political reports, as well as brochures from international and national specialized organizations.

The situation should be noted that the reason for the special interest of representatives of various Sciences to the problems of environmental migration as a specific type of population movement caused by adverse natural phenomena as disasters, catastrophes and man-made processes, is an exceptional increase in the share of environmental migration in the total volume of migration processes in the world - this is substantiated by the estimates of UN University experts, who believe that tens of millions of people around the world will be forced to abandon their homes due to devastating natural disasters, soil depletion, droughts, etc [10].

\section{Methodology}

Migration is one of the most pressing issues in the global politics. Although we can say that there is no one who is not familiar with migration, nevertheless, politicians recognize the complexity of managing it, and scientists note that there is no unity in understanding its essence, nor common approaches to its study.

The multi-causality of environmental migration is the point at which all scientists dealing with this problem converge. The scientific community agrees that the methodological basis for the study of migration processes, including the causes of environmental changes, can only be a comprehensive, interdisciplinary approach. Based on this, it should be noted the variety of methods and theoretical approaches in the study of migrations. In the works of scientists are proposed mechanisms and methods for a systematic approach to the classification, characterization and typology of migration in making clear distinctions between sociological and political approaches, and so on. Thus, Caroline Bretell and James Holyfield present a matrix that summarizes the main research issues and methodologies, as well as the dominant ones in each of the presented disciplines [11]. The geographer of U.S. Department of State William wood proposes to use the term «emigrant» which is broader and includes all persons, migration which is caused by factors of environmental change. He emphasizes the ambiguity of the prefix «eco», which can be used to refer to both environmental and economic factors [12].

According to Frank Duval, customary theories are criticized, for example, for being detached from reality, while new-fangled theories are often limited to conducting research on a descriptive level [13]. Regrettably, modern science cannot develop a methodology for constructing a migration classification. There is not yet an available set of methods for determining all categories of spatial mobility of the population. 


\section{Discussion}

\subsection{The goal of Sustainable development}

At the end of September 2015, a significant event occurred at the UN summit in New York - instead of the Millennium development Goals (MDGs), which expired in 2015, the sustainable Development Goals (SDGs) were adopted for 2016- 2030. The UN outcome document on the results of the MDGs notes that at present «the world is at a historical crossroads» [14]. The commitments made by world leaders are unprecedented: they promise to take joint movements and efforts to realize such a large-scale and comprehensive strategic program as the SDG [15]. From the methodological standpoint, the MDGs are in line with the priority theoretical concept of the UN-human development. Many of the methodological developments of the UN structures in the field of human development formed the basis of the Millennium Declaration and the corresponding Goals (2000). A crucial advantage of the MDGs was the transformation of the most important priorities of humanity (such as overcoming poverty, improving the quality of education, healthcare, etc.) into a system of clearly defined tasks and (which is especially valuable) quantitative indicators that allow us to assess the dynamics (positive or negative) in their implementation [16].

The New era development goals not only contain verification of commitments to achieve them, but also mark new heights in areas such as eliminating inequality, stable economic evolution, creating affordable jobs, increasing megacities and other humanoid resolutions, industrialization, energy progress, combating climate change, maintainable consumption and production patterns, inclusive peace, objectivity and the development of institutions. An environmental perspective is present in the vast majority of items on the agenda. Creating a world partnership, identified as a divided goal, is defined as the main instrument for achieving the sustainable development aims.

Transitional goals are presented here as a complementary instrument to international documents (international conventions, treaties, agreements and communiques), creating normative boundaries of relations between countries, attracting and giving motivation to interested parties to work.

The SDGs cover the major priorities of sustainable development much more broadly than the MDG. The SDG is a more balanced system that includes all three components, the three pillars of sustainable development:

-the social sphere;

-the economy;

-the environment.

It is extraordinary that most of the goals and objectives of the SDG are not monologues, but can cover all elements of sustainable growth.

The final materials of the UN Summit on the adoption of the post-2015 development agenda identify five areas that are the basis for realizing the goals and objectives of sustainable growth.

1. About peace. For the purposes of sustainable development, it is stated that the world community is steadily striving for world peace, justice, and a society without social barriers, where there is no fear or violence. There can be no sustainable development without peace and peace without sustainable development.

2. About partnership. For sustainable development, it is stated that the world community is constantly striving to use all the opportunities that will help in the implementation of this agenda within the framework of an updated Global partnership for sustainable development. It proceeds in the direction of increased international solidarity, focuses primarily on meeting the needs and 
demands of the poorest and most vulnerable groups, and involves the involvement of all States, all inhabitants of the planet [14].

3. About people. The sustainable development Goals indicate that the world community is committed to ending poverty and hunger in all their forms and manifestations and to doing everything possible to ensure that all citizens of the world are able to realize their potential in dignity and equality and in a favorable environment.

4. About the planet. For the purposes of sustainable development, it is stated that the world community is steadily striving to protect the planet from collapse, using as tools the introduction of meaningful consumption and production models, the appropriate use of natural potential and taking urgent measures in connection with climate change, in order to preserve the planet's ability to meet the needs of current and future generations [14].

5. About prosperity. For sustainable development stated that the global community is committed to achieve conditions in which the inhabitants of the planet will live in a prosperous and affluent society, where the progress of the economy, the social sphere and technology is subject to natural factors [16].

A comprehensive solution to the issues associated with the five areas identified is a priority for the UN in implementing the sustainable development aims. One of the most acute problems in this context is the problem of environmental migrants.

\subsection{Environmental migration in the context of the UN sustainable development concept}

There are several groups of migrants in the global migration flow. These are labor, environmental, illegal migrants, refugees, asylum seekers, and members of reuniting families. Balancing the goals and interests of donor and recipient countries is carried out in the process of regulation and coordination of actions. Only under these circumstances can we expect a permanent economic recovery and sustainable development. This is particularly relevant because a significant share of migration is made up of economic migrants. The implementation of Goal 1 of the 2030 Agenda, which involves the elimination of poverty and poverty in all its manifestations, is achieved through freedom of movement.

The refinement of indices related to spatial movements in achieving the sustainable development Goals is determined by changes in the qualitative and quantitative indicators of human resources. Migration is not only a source of reserve labor potential, which ensures the competitiveness of the economic sphere. Highly qualified migrants contribute to technological modernization and the transition to innovation in the economy.

Migration can help overcome threats of global challenges, such as threats to life during military operations, environmental and man-made disasters. The expanding human impact on nature, natural phenomena caused by human activity, lead to serious changes in its quality; along with this, the economy and the way of life of people change, which leads to their spatial movement, as they fear for their lives.

Assessing the extent of the impact of climate change on spatial movements is related to understanding the causes of various types of migration mobility, only some of which are determined by environmental factors. It happens that climate threats do not lead to unaccountable movements of people and migration becomes an adaptation strategy.

The scientific discourse on this problem could be more fruitful if scientists took into account the types of temporary movements, for example, for a period of less than three months, short-range migrations, which range from three months to a year, and long-range migrations, that is, for a period of more than a year. Rising sea levels or desertification are more likely to lead to long-term migrations, while unpredicted, quick disasters (tropical cyclones, hurricanes, typhoons) are more likely to lead to temporary actions of persons. 
Yet, this typology is far from perfect: for example, droughts lead to seasonal migration, which involves moving from one region to alternative one and back. Moreover, there is a significant difference between migrations over short and long distances, between movements within one's own state and inter-country traffic [18]. Debates on the impact of climate change on spatial movements often focus only on cross-country migration and, especially, on the direction of migration flows from southern regions to northern regions. Nevertheless, this is more likely to represent phobias of Western, prosperous countries than real trends, since most of the migration processes are a sample of internal movement [7]. Such, for example, is migration in Kazakhstan from the region of ecological disaster in the Aral sea region, which will be discussed under.

At the same time, it is required to distinguish between voluntary and forced migration. Often, the term «environmental migrant» - a refugee under the influence of environmental factors-implies that people are forced to relocate due to the influence of environmental factors. However, in fact, the differentiation between forced and voluntary migration seems to be quite a difficult issue.

Worldview discrepancy remain the key source of talk on the influence of climate change on migration. There are scientific and political differences in the interpretation of such categories as «environmental migrants» or «climate change refugees» as an example.

The symbiosis of concepts such as «environment» («climate») and «migrants» («refugees») is criticized because it implies a one-sided, limited relationship between spatial movements of people and environmental factors. Then the diversity and complexity of explanations of this phenomenon are denied. According to Casles, «the term «refugee» under the influence of environmental factors seems simplistic, one-sided and disorienting. It implies a single cause, which is extremely rare in practice» $[18, \mathrm{p}$. 5]. Based on this, it is not possible to authenticate a group of people who migrate solely for reasons of ecological drivers.

If we dialogue about the political aspect, the discourse concerns the use of the term «refugee». Based on the 1951 UN Geneva Convention, «refugee» means a status that applies to persons who leave their country because of a reasonable fear of persecution for reasons of race, religion, nationality, belonging to a particular social group, or political beliefs of a citizen. Clearly, that the reasons for migration related to the environment are absent in this definition, and this leads to two opposing points of view: on the one hand, this is a broader interpretation of the meaning, on the other hand, the possibility of not using the concept of «refugee» in the case of climate change, for fear of replacing a clearly defined category of people with a concept that has a broader understanding. This has led to changes in terminology relating to environmental refugees, while these terms are not reflected in worldwide refugee documents, and most of those who are frequently identified as refugees for reasons of environmental changes only carry out inner migration. «The use of these terms potentially leads to the undermining of international legitimacy in the field of refugee protection and creates chaos in the interpretation of the relationship between climate change, environmental disgrace and migration» [19, p. 7].

It may be assumed that the complexity of the issue will lead to a lack of consensus in the foreseeable future; differences in the interpretation of terms and concepts are likely to remain intractable [7]. However, theoretical discussions of scientists regarding the semantics of certain terms should not prevent a multi-dimensional analysis of various types of spatial movements of people under the influence of natural disaster factors [20].

In other words, the differences of the participants in the debate about the scientific categorical apparatus of the issues should not prevail over the overall vision of the subject matter - multiplechannel migration, social absoloutely the vulnerability of migrants, etc. And especially should not interfere with the development of a common approach to issues on the agenda, which is the main challenge for the scientific and political environment. 


\subsection{Environmental migration in the Aral sea region}

Currently, it is recognized that the Aral crisis is one of the largest environmental and socio - economic crises created by people in the XX century because of the desire to obtain economic benefits, without paying attention to possible negative environmental consequences. The fall in sea level triggered the process of desertification in the Aral sea region, resulting in a reduced quality of living environment and deteriorating socioeconomic conditions for three million people. For a decade the population used water with excessive salt content and the presence of toxic chemicals for drinking; until now, dust storms are a common phenomenon; jobs and additional natural sources of food were lost (hunting and commercial animals disappeared due to the death of riparian forests and tall grass; rivers, reservoirs, and the sea lost their fishing significance), soil fertility deteriorated, and crop yields decreased. The development of the crisis and the practical actions taken to address various problems that have arisen in connection with the fall in sea level and desertification, the environmental situation in the Aral sea region has now become the norm.

In order to prepare the basis for discussion of environmental and climate migration in Kazakhstan and Central Asia, a study «Environmental migration and its consequences for social policy on the example of the Kyzylorda region» was conducted in 2013 as part of the working report of the UNESCO Cluster office [21].

The research based on the study of social vulnerability of focus groups in three cities in the southern regions of Kazakhstan, revealed the relationship between current climate changes, environmental degradation and non-economic losses expressed in migration of the population from the affected regions. The main materials were presented in three sections: Environmental (climate) migration in the context of international migration law, International approaches to determining climate migration, and a Sociological study «the Impact of environmental factors on population migration in the Aral sea region». The section «environmental Regulation of migration in the framework of national legislation» States that Kazakhstan law, the person moved within the country for environmental reasons, is determined by the Law of July 22, 2011 No. 477-IV «On population migration» [22]. Such a person is recognized as a migrant and is considered as «a person moving within the Republic of Kazakhstan in accordance with the quota for the resettlement of internal migrants from localities with particularly unfavorable environmental conditions and low development potential to economically promising regions of the Republic of Kazakhstan for permanent residence». This definition is based on demographic trends and the impact of environmental factors on the health of the population in vulnerable areas. This is shown in the data on internal migration in the Kyzylorda region given in figure 1.

Figure 1. Internal migration in the Kyzylorda region 


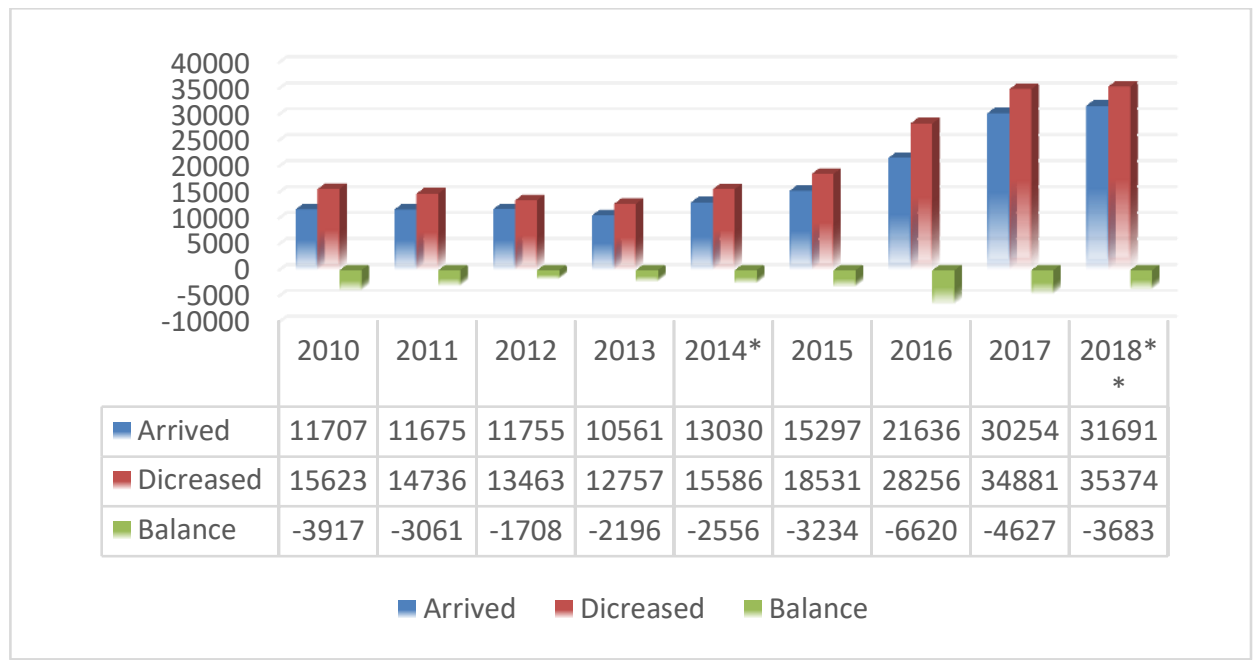

Source: * Demographic Yearbook of Kazakhstan. [23, p.254]

** Demographic Yearbook of Kazakhstan. [24, p.271-272]

Thus, the table shows that for almost the entire decade there was a stable decline (negative balance of internal migration) of the population from the Kyzylorda region; even the arrival of international migrants, for which there was a positive balance in some years, occurred in the Kyzylorda region mainly within the framework of the "oralmans'» repatriation program, as can be seen from the countries of the outcome of such migration to the region (Uzbekistan, Russia, Kyrgyzstan and Mongolia).

Table 1 shows that external migration over the past five years has also been negative.

Table 1. The intensity of external migration in the Kyzylorda region (per 1000 people).

\begin{tabular}{|c|c|c|c|}
\hline Year & Immigrants & Emigrants & Balance of migration \\
\hline 2010 & 0,34 & 0,18 & 0,25 \\
\hline 2011 & 0,11 & 0,07 & 0,1 \\
\hline 2012 & 0,07 & 0,09 & 0,06 \\
\hline 2013 & 0,08 & 0,05 & 0,02 \\
\hline $2014^{*}$ & 0,07 & 0,05 & 0,03 \\
\hline 2015 & 0,02 & 0,08 & $-0,06$ \\
\hline 2016 & 0,02 & 0,08 & $-0,07$ \\
\hline 2017 & 0,04 & 0,07 & $-0,03$ \\
\hline $2018^{* *}$ & 0,05 & 0,09 & $-0,04$ \\
\hline
\end{tabular}

Source: * Demographic Yearbook of Kazakhstan. [23, p.253]

** Demographic Yearbook of Kazakhstan. [24, p.271]

Figure 2. External migration from Kyzylorda region (2006-2011) 


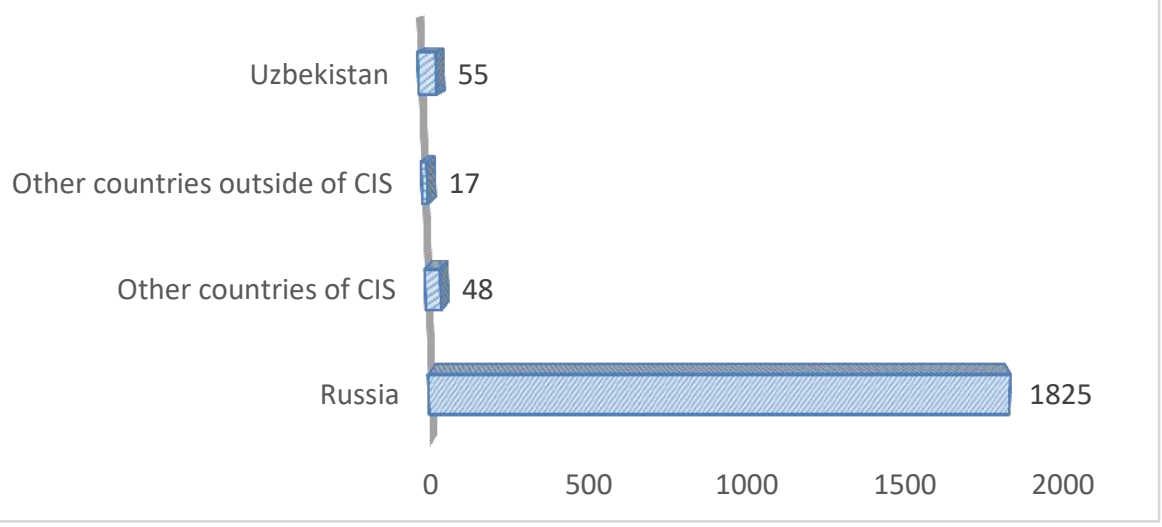

Source: [21].

One of the probable causes of morbidity, as a consequence of the high level of environmental migration, in the Kyzylorda region is still poor quality of drinking water. Based on the results of water samples taken in the period from 2014 to 2018, residents of the Kyzylorda region receive low-quality drinking water through the centralized water supply system, and the maximum permissible concentrations of harmful substances exceed the norms by 3-4 times in some indicators (Table 2).

Table 2. State of water for drinking and cultural water use in the Aral region of the Kyzylorda region

\begin{tabular}{|c|c|c|c|c|}
\hline \multirow[t]{2}{*}{ Years } & \multirow{2}{*}{$\begin{array}{l}\text { Place of } \\
\text { selection }\end{array}$} & \multicolumn{3}{|c|}{ Contaminants in excess of MPC } \\
\hline & & Ingredients & $\begin{array}{l}\text { The average } \\
\text { concentration of } \\
\text { mg / l }\end{array}$ & MPC excess ratio \\
\hline \multirow[t]{18}{*}{2013} & \multirow{6}{*}{ Outdoor pond } & Turbidity & 1,6 & 1,1 \\
\hline & & Color & 37 & 1,5 \\
\hline & & Rigidity & 7,5 & 1,1 \\
\hline & & Dry residue & 1115,3 & 1,1 \\
\hline & & Magnesium & 48,74 & 1,2 \\
\hline & & Sulphates & 576,7 & 1,2 \\
\hline & \multirow[t]{2}{*}{ Deep wells } & Sulphates & 510 & 1,0 \\
\hline & & Color & 29 & 1,2 \\
\hline & \multirow[t]{4}{*}{ Water pipes } & Turbidity & 1,54 & 1,0 \\
\hline & & Magnesium & 48,7 & 1,2 \\
\hline & & Dry residue & 1056 & 1,1 \\
\hline & & Sulphates & 515 & 1,0 \\
\hline & \multirow{6}{*}{$\begin{array}{l}\text { Decentralized } \\
\text { sources }\end{array}$} & Turbidity & 1,7 & 1,1 \\
\hline & & Color & 26 & 1,0 \\
\hline & & Rigidity & 7,5 & 1,1 \\
\hline & & Dry residue & 1072,3 & 1,1 \\
\hline & & Magnesium & 54,8 & 1,4 \\
\hline & & Sulphates & 603,3 & 1,2 \\
\hline
\end{tabular}




\begin{tabular}{|c|c|c|c|c|}
\hline \multirow[t]{12}{*}{2014} & \multirow{6}{*}{ Outdoor pond } & Turbidity & 1,63 & 1,1 \\
\hline & & Color & 26,5 & 1,1 \\
\hline & & Rigidity & 7,1 & 1,0 \\
\hline & & Dry residue & 1081,8 & 1,1 \\
\hline & & Magnesium & 48,7 & 1,2 \\
\hline & & Sulphates & 530 & 1,1 \\
\hline & \multirow{6}{*}{$\begin{array}{l}\text { Decentralized } \\
\text { sources }\end{array}$} & Turbidity & 1,83 & 1,2 \\
\hline & & Color & 25 & 1,0 \\
\hline & & Rigidity & 7 & 1,0 \\
\hline & & Dry residue & 1109 & 1,1 \\
\hline & & Magnesium & 54,8 & 1,4 \\
\hline & & Sulphates & 552,7 & 1,1 \\
\hline \multirow[t]{12}{*}{2015} & \multirow{6}{*}{ Outdoor pond } & Turbidity & 2,0 & 1,3 \\
\hline & & Color & 85 & 3,4 \\
\hline & & Rigidity & - & - \\
\hline & & Dry residue & 1209 & 1,0 \\
\hline & & Magnesium & 40 & 1,0 \\
\hline & & Sulphates & 592,5 & 1,2 \\
\hline & \multirow{6}{*}{$\begin{array}{l}\text { Decentralized } \\
\text { sources }\end{array}$} & Turbidity & 1,6 & 1,1 \\
\hline & & Color & 39 & 1,6 \\
\hline & & Rigidity & - & - \\
\hline & & Dry residue & 1192,5 & 1,2 \\
\hline & & Magnesium & - & - \\
\hline & & Sulphates & 577,5 & 1,2 \\
\hline \multirow[t]{12}{*}{2016} & \multirow{5}{*}{ Outdoor pond } & Turbidity & 1,6 & 1,1 \\
\hline & & Color & 83,8 & 3,4 \\
\hline & & Dry residue & - & - \\
\hline & & Magnesium & - & - \\
\hline & & Sulphates & 531,8 & 1,1 \\
\hline & Deep wells & Color & 36,25 & 1,4 \\
\hline & Water pipes & Color & 35,5 & 1,4 \\
\hline & \multirow{5}{*}{$\begin{array}{l}\text { Decentralized } \\
\text { sources }\end{array}$} & Turbidity & - & - \\
\hline & & Color & 47,5 & 1,9 \\
\hline & & Dry residue & - & - \\
\hline & & Magnesium & 42,63 & 1,1 \\
\hline & & Sulphates & - & - \\
\hline \multirow[t]{6}{*}{2017} & \multirow{6}{*}{ Outdoor pond } & Turbidity & 1,55 & 1,0 \\
\hline & & Color & 47,5 & 1,2 \\
\hline & & Rigidity & 1044 & 1,0 \\
\hline & & Dry residue & 45,70 & 1,1 \\
\hline & & Magnesium & - & - \\
\hline & & Sulphates & 7,8 & 1,1 \\
\hline \multirow[t]{7}{*}{2018} & \multirow{6}{*}{ Outdoor pond } & Turbidity & 1,5 & 1,0 \\
\hline & & Color & 34,5 & 1,4 \\
\hline & & Rigidity & 1208,75 & 1,2 \\
\hline & & Dry residue & 44,2 & 1,1 \\
\hline & & Magnesium & - & - \\
\hline & & Sulphates & 8 & 1,1 \\
\hline & Decentralized & Color & 27 & 1,1 \\
\hline
\end{tabular}




\begin{tabular}{|l|l|l|c|c|}
\hline \multirow{2}{*}{ sources } & Dry residue & 500 & 1,0 \\
\cline { 3 - 5 } & & Sulphates & 1006,75 & 1,0 \\
\hline
\end{tabular}

Source: [25].

Based on the data of surveys conducted among the residents of the Aral sea region, it can be concluded that the main possible reasons for migration are socio-economic. However, it should be noted that there is an indirect correlation between the state of the region's ecology and the socio-economic situation of its inhabitants. Many international organizations that Finance Ural environmental programs also pay attention to this: instead of fighting the root cause (the natural degradation of the Aral sea region), the authorities are only trying to mitigate its consequences. Another feature of environmental migration from the crisis zone is its international character, confirmed by the Nukus Declaration in 1995 on sustainable development of the Aral region [26].

During the entire period of independence, the Uzbekistan authorities have supported the flow of migrants from Karakalpakstan to Kazakhstan. According to unofficial data, especially during the early 2000s, when a terrible drought was raging in Karakalpakstan, more than 100 thousand people moved to Kazakhstan. Sparsely populated region strategically important for Uzbekistan, remains in its composition, but becomes more ethnically homogeneous (occurring everywhere Uzbekistani district), less populated (reduced the volume and so little help in overcoming the consequences of the Aral crisis), which pushes Karakalpaks and ethnic Kazakhs of Uzbek citizens migrate to Kazakhstan.

\section{Results}

Today, environmental migration is a generally recognized phenomenon that takes on a mass character. The reasons for environmental migration are very diverse and often do not work directly, which leads many scientists to consider such migration as an adaptive strategy.

In the case of the Aral sea region, the sustainable development Goals, acting as a road map, can indicate the main areas of action to overcome the consequences of the environmental crisis and the increasing scale of environmental migration. In this context, in our opinion, it is worth paying close attention to the following points the following aspects:

1. Goal 3 of the SDG States: by 2030, significantly reduce mortality and morbidity due to exposure to hazardous chemicals and pollution and poisoning of water, air and soil.

2. Goal 6 in the SDG is multidimensional in content. It sets out the following goals: 2030 should be a milestone in ensuring universal and equal access to safe and affordable drinking water for everyone.

3. In addition, Goal 6 aims to improve water quality by 2030 by reducing pollution, eliminating waste discharges and minimizing emissions of hazardous chemicals and materials, halving the percentage of untreated wastewater, and significantly increasing the recycling and safe reuse of wastewater worldwide.

4. It is also necessary to significantly improve the efficiency of water use in all economic sectors by 2030, and ensure a sustainable intake and supply of fresh water to address water scarcity and significantly reduce the number of people suffering from water scarcity; to approach water resources management at all levels in an integrated manner, including through cross-border links, and to multiply efforts to protect and preserve the world's cultural and natural heritage.

5. In order to achieve Goal 11, "ensuring the openness, security, resilience and environmental sustainability of cities and localities", the goal is to maintain positive socio-economic and environmental links between different localities based on improving the quality of national and regional development planning $[27,28]$. 
6. Goal 13, related to taking urgent measures to combat climate change and its consequences, aims to improve education, empower each individual and the community as a whole to address climate change, and develop adaptive and preventive mechanisms.

7. The objectives of Goal 15 for the protection and restoration of terrestrial ecosystems are to combat desertification and restore degraded lands [15] and soils. Also, humanity should strive to preserve and improve the state of the land [27].

However, it cannot be denied that the General degradation of nature increases the vulnerability of all mankind and requires immediate action, both locally and globally. In order to build effective assistance programs to prevent environmental migrations and combat their consequences, it is necessary to work closely with experts and specialists in various fields of science, based on the recommendations of the UN sustainable development Goals.

The article was prepared as part of the scientific project of the Ministry of Education and Science of the Republic of Kazakhstan No. AR05135403 “The Diaspora Factor of Kazakhstan's Foreign Policy and Diplomacy in Relations with European Countries".

\section{References:}

1. D.V.Ivanov, D.K. Bekyashev, Ekologicheskaya migraciya naseleniya, Mejdunarodno_pravovie aspekti. - M.-S.10. (2013)

2. Official website of the International Organization for Migration. http://www.iom.int/cms/en/sites/ iom/home /what-we-do/migration-and-climatechange/definitional-issues.html

3. Regionalnaya konferenciya po rassmotreniyu voprosov bejencev, nedobrovolno peremeschennih lic,drugih form nedobrovolnih peremeschenii $n$ vozvraschayuschihsya lic $v$ stranah SNG $n$ sootvetstvuyuschih sosednih gosudarstvah_Jeneva, 30-31 maya 1996 g.- per. s angl. -Jeneva_41 s. (1996)

4. Nyu-Iorkskaya deklaraciya o bejencah i migrantah // https://www.iom.int/

5. M. Gubaidullina, B.Janusz-Pawletta, Legal framework for management of transboundary waters in Central Asia to strengthen interstate cooperation and increase regional security. In: Cahiers d'Asie central (CAC25). Littérature et Société en Asie Centrale. AFEAK (Ed. PETRA). -- № 25 (Dec.), P. 195-215 (2015); L.Issova, A. Milan, Qytaidyń ekologllalyq salasatyndaǵy ishki jáne jahandyq máseleler. // QazUÝ Habarshysy (HQ jáne HQ serıasy). №1 (81) bb.123132. (2018)

6. N. Myers, Environmental refugees in a globally warmed world // Bioscience.- №43 - P. $752-761$ (1993); $\quad$ T. Afifi, K. Warner The impact of environmental degradation on migrations flows across countries. // United Nations University EHS - Working Paper. -№5 - 25 p. (2008)

7. E. Pige, A. Peku, P. De Gyuktener, Migraciya naseleniya i izmenenie klimata // Geografiya i prirodnie resursi. - №2. - S.5-14 (2013)

8. V.I. Evtushenko, Ekologicheskaya migraciya kak element realizacii prava grajdan Rossii na blagopriyatnuyu okrujayuschuyu sredu. M.: Prospekt, - 192 s. (2019); E.Yu. Markova, Mejdunarodno-pravovaya zaschita ekologicheskih migrantov: realii i perspektivi. Aktualnie problemi rossiiskogo prava- №7. - S.209-217 (2018); M.K. Garsia, The Refugee Challenge in Post-Cold War America. New York: Oxford University Press Pp. XII, 340 (2017) 
9. N.V. Rogojina, Izmenenie klimata i problema migracii v stranah YuVA. // YugoVostochnaya Aziya: aktualnie problemi razvitiya.- №20. - C.139-146 (2013); N.M. Novikova, Ekologo_geograficheskii aspekt Aralskogo krizisa. - Ekosistemi: ekologiya i dinamika. T.3. - №1. - S.5-66 (2019)

10. Science et Vie.- №1060. - P.28. (2006)

11. Migration Theory: Talking across discipline (2000) Ed. by B. Caroline Brettell and F. James Hollifield. Routledge // Taylor \& Francis Group, NY and London, pp. 97136

12. N.Myers,, J. Kent, Environmental exodus. An emergent crisis in the global arena. ClimateInstitute, P. 17 (1995); S. Castles, Environmental change and forced migration: making sense of the debate // NewIssues in Refugee Research. Working Paper №70. - P. 9. (2002)

13. Bill Jordan and Franck Düvell, Irregular Migration: The Dilemmas of Transnational Mobility, Cheltenham, UK and Northampton, MA: Edward Elgar, VIII+284 pp. (2002)

14. Millennium Development Goals Report 2015. United Nations, New York, 74 p. (2015)

15. Transforming our World: the 2030 [Agenda for Sustainable Development]. United Nations, 45 p. (2015)

16. S.N. Bobylev, S.V. Solovyeva, OON: smena zeley. // Mirovaya ekonomika I mezhdunarodnye otnosheniya. - №5. - S.30-39 (2016)

17. E. Mooney, The concept of internal displacement and the case for internally displaced persons as a category of concern // Refugee Survey Quarterly.- №24 (3). - P. 9-26. (2005)

18. S. Castles, Environmental change and forced migration: Making sense of the debate // New Issues in Refugee Research - UNHCR Research Paper.- №70 - 14 p. (2002)

19. Climate change, natural disasters and human displacement: A UNHCR perspective. - Geneva: UNHCR,- 12 p. (2009)

20. W. Kaelin, The climate change - diplacement nexus // ECOSOC Panel on Disaster Risk Reduction and Preparedness: Addressing the Humanitarian Consequences of Natural Disasters. (2008)

21. V.Ni, A.Tonkobaeva, A.Ilyasova, Ekologicheskaya migraciya i ee posledstviya dlya socialnoi politiki na primere Kizilordinskoi oblasti. //Klasternoe byuro YuNESKO v Almati po Kazahstanu, Kirgizstanu,Tadjikistanu i Uzbekistanu. Almati_ 47 str. (2013)

22. «O migracii naseleniya»// https://online.zakon.kz/document/?doc_id=31038298\# pos=3;-155

23. Demograficheskii ejegodnik Kazahstana. Statisticheskii sbornik (na kazahskom i russkom yazikah). // Astana, - 262 s. (2015)

24. Demograficheskii ejegodnik Kazahstana. Statisticheskii sbornik (na kazahskom i russkom yazikah). // Astana, - 279 c. (2019)

25. Informacionnie byulleteni o sostoyanii okrujayuschei sredi i zdorovya naseleniya Priaralya. Za 2014-2018 gg.// http://ecogeo.gov.kz/ ru/kategorii/ekologicheskiybyulleten

26. Nukusskaya deklaraciya gosudarstv Centralnoi Azii i mejdunarodnih organizacii po problemam ustoichivogo razvitiya basseina Aralskogo morya (g. Nukus, 20 sentyabrya 1995 g.) // http://mkur.uznature.uz/rus/ nukusdeklaraciya.html

27. Celi v oblasti ustoichivogo razvitiya //www.un.org/sustainable development/ru/sustainable-development-goals/ 
28. Bosáková, I., Kubíček, A., \& Strouhal, J. Economics \& Sociology, 12(3), 251-272. (2019). 